francophone patients are forced to travel to anglophone-run hospitals, where bilingual services are lacking.

The province acknowledges the disparity between the two regions, but Theriault says that's one of the reasons why the overhaul was needed: to close the gap and boost services in region $\mathrm{A}$.

"We have improved the quality and level of services for francophones by making things more efficient and by establishing a line of communication," he says.
For Dr. Bernard Leduc, the New Brunswick legal fight clearly resembles a battle fought a decade ago over Montfort Hospital in Ottawa, Ontario.

In the late 1990s, an Ontario commission recommended closing Montfort Hospital as part of a restructuring plan.

The proposal, however, was successfully challenged in the Ontario courts, which concluded that as a cultural institution, the Montfort was essential to the survival and well-being of the Franco-Ontarian community, and that its closure was unconstitutional.

"The judgment recognized that Montfort was more than a hospital that it was a very important institution in preventing assimilation. It was a way for the francophone culture in Ottawa to sustain itself," says Leduc, a family physician and the hospital's chief executive officer. "The minority rights of francophones are not negotiable." Quentin Casey, Halifax, NS

DOI:10.1503/cmaj.109-3216

\title{
Health care in Romania: Fighting collapse
}

Previously published at www.cmaj.ca

"With a 2010 health care budget of $3.6 \%$ of GDP, Romania comes last in the European Union in terms of health care financing. Moreover, since that the last trimester of 2009 was financed with credits from the 2010 budget, the real figure for this year is around $2.3 \%-2.6 \%$ of GDP. This money will only last until July 2010." — Romanian College of Physicians in a Jan. 7 press release

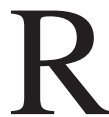

ather remarkably, Atilla Cseke, Romania's minister of health, didn't dispute the notion that his country's health care system is so underfinanced that it is facing imminent collapse. "We must find additional financial resources for the second half of 2010," he told a press conference in late January.

Cseke's hopes of staving off collapse rest on more efficient use of existing funds, elimination of waste and the introduction of copayments.

Yet, miracles shouldn't be expected.

For years, Romania's health care system has struggled to cope with underfunding.

Most hospitals in the country are in debt and even large university hospitals often lack basic supplies, such as surgical gloves and antibiotics, forcing patients to pay for such amenities out of pocket. Many buildings are in serious need of repair and sanitization. The conditions - most of which Canadians could not imagine - are fodder for the

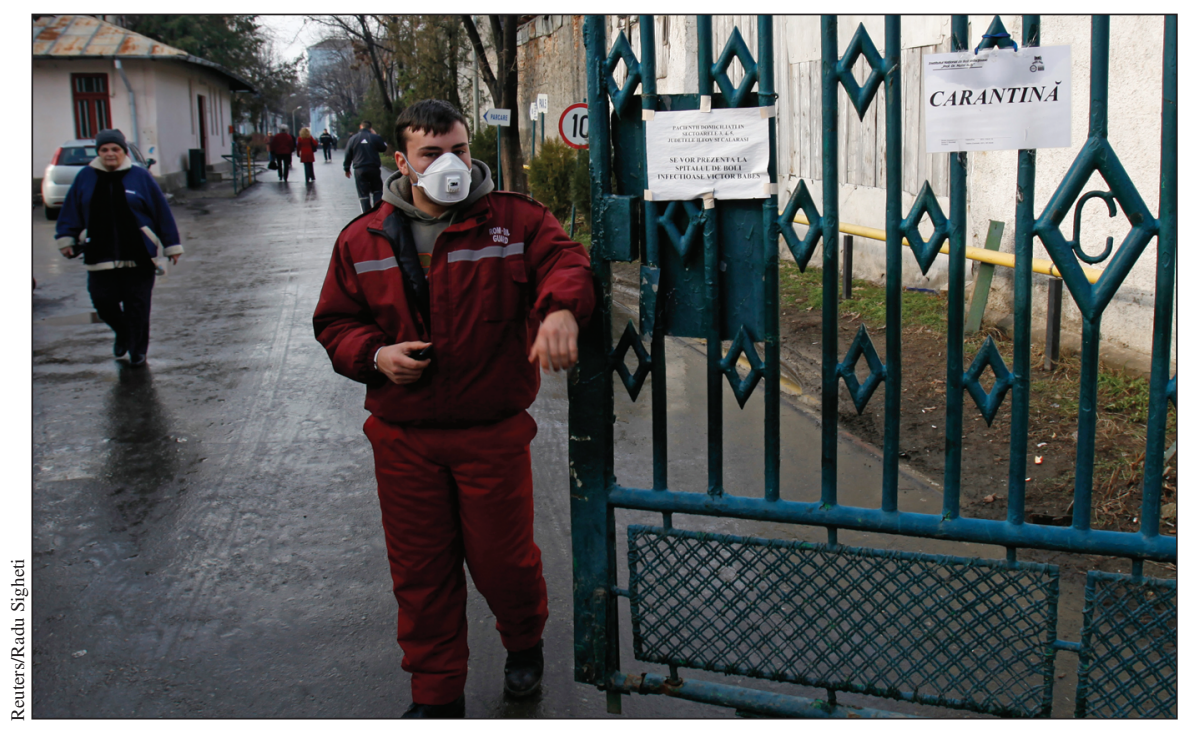

A guard closes the gate of Matei Bals Hospital, where Romanians had queued to be vaccinated against the pandemic (H1N1) 2009 flu virus in January.

media. Imagine rusted surgical instruments, rusted examination beds, cracked and damp walls, dirty toilets and, occasionally, cockroaches.

These may be extreme examples, but the fact remains that for a European Union country in the 21st century that has managed advances in many other sectors of the economy and society, health care continues to lag significantly behind.

The country has had a mandatory health insurance scheme covering all citizens since 1998, administered by a National Insurance House that contracts services from providers. But it is chronically underfunded and notoriously inefficient in allocation of resources.

Compounding the problem is the medical brain drain faced by Romania, which now has one of the lowest ratios of physicians per population in Europe (Box 1). The Romanian College of Physicians reported that more than 4000 doctors - mostly junior doctors - have emigrated since 2007, representing almost $10 \%$ of doctors in the country.

The primary reason is financial: salaries for young doctors in Romania are 10-to-15 times lower than in Western Europe and low in comparison to the average Romanian salary. A resident in Romania typically earns $€ 200$, as compared the average worker's salary of $€ 320$.

"I don't want to leave Romania, my family and friends," says a young doc- 
tor, who requested anonymity. "But it's humiliating to have parents pay my bills at the age of 35, after years of training and hard work in the hospital."

Working conditions are also a factor. "I want to have the resources to practise real medicine, without worrying that basic drugs are not available in the hospital pharmacy or the CT scan is broken," he adds.

The brain drain has been fuelled by demand for physicians in many Western European countries, particularly Germany, France and several Nordic nations. Romania's entry into the European Union in 2007 made it easier for those countries to import Romanian doctors willing to relocate. In October 2009, Bucharest held a medical job fair during which more than 2000 jobs from around the world were up for grabs.

The shrinking of the workforce is hitting hardest in rural areas and smaller cities where working conditions are toughest. Large university centres, though, remain overcrowded with doctors in most specialties. "Twothirds of the doctors in the country are concentrated in six centres," says Dr. Vasile Astarastoae, president of the Romanian College of Physicians.

Complicating matters are informal payments to physicians for their services, which a market and social research institute, the Bucharest-based Centre for Urban and Regional Sociology, pegged at $0.3 \%$ of Romania's gross domestic product in a 2008 survey.

Doctors find the compensation attractive because of low salaries. But the payments have had a dramatic impact on equity of access to services and the public image of doctors. Thus far, though, the government has not taken action to quash the practice.

In the face of such developments within the troubled public health care system, there has been significant growth in a parallel, private system.

That's been primarily driven by clinic chains that were created with corporate sponsorship, primarily in Bucharest. They've since expanded to other cities and serve individuals, along with corporations. Many find the clinics attractive because they offer medical services at a level comparable to those in developed Western countries.

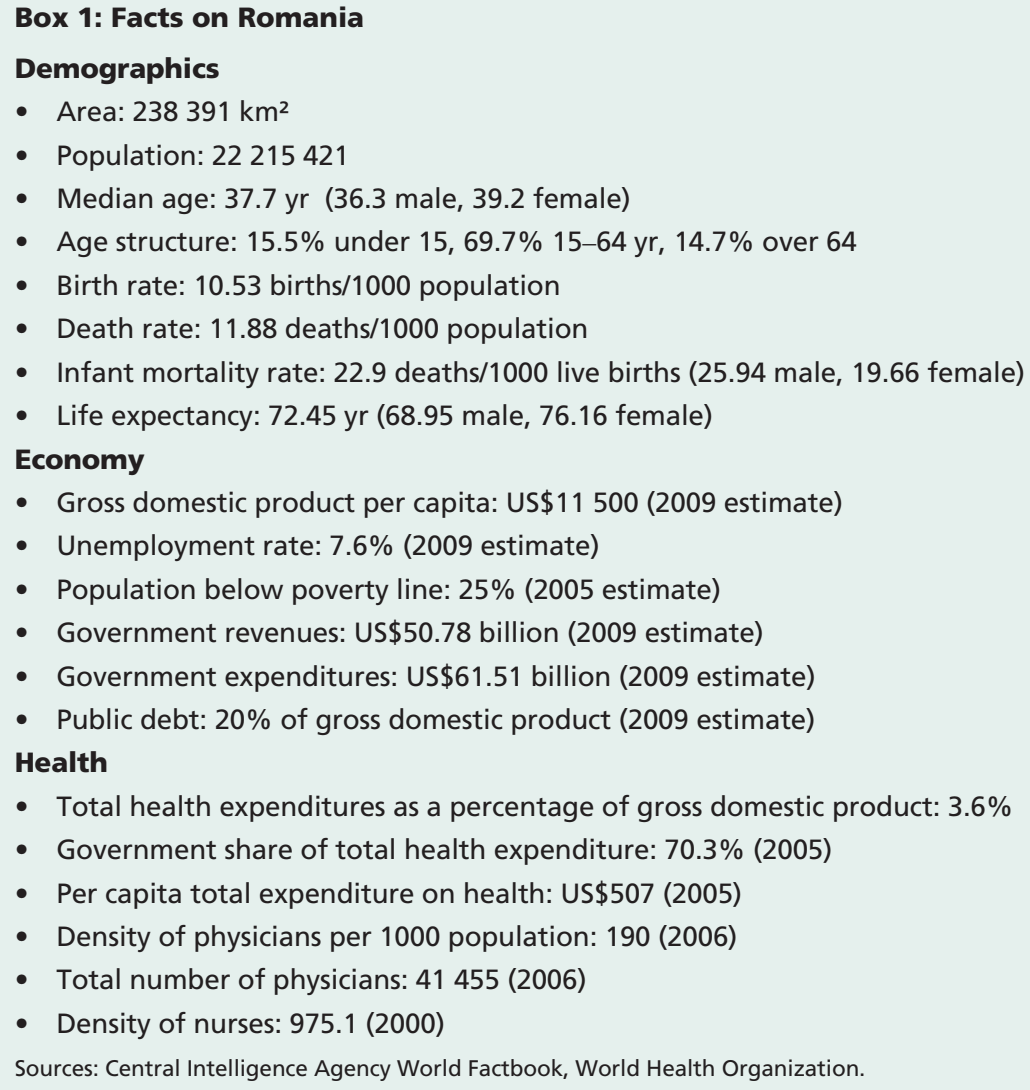

- Gross domestic product per capita: US\$11 500 (2009 estimate)

- Unemployment rate: $7.6 \%$ (2009 estimate)

- Population below poverty line: $25 \%$ (2005 estimate)

- Government revenues: US\$50.78 billion (2009 estimate)

- Government expenditures: US\$61.51 billion (2009 estimate)

- Public debt: $20 \%$ of gross domestic product (2009 estimate)

\section{Health}

- Total health expenditures as a percentage of gross domestic product: $3.6 \%$

- Government share of total health expenditure: $70.3 \%$ (2005)

- Per capita total expenditure on health: US\$507 (2005)

- Density of physicians per 1000 population: 190 (2006)

- Total number of physicians: 41455 (2006)

- Density of nurses: 975.1 (2000)

Sources: Central Intelligence Agency World Factbook, World Health Organization

But such clinics tend to focus on more profitable segments or outpatient services such as gynecology, dermatology and some surgeries, and leaving more complex and costly therapies to the public sector.

Left in the wake of such developments are the patients, who face everpoorer health outcomes. In 2009, the Euro Consumer Health Index, a comparative measure of 33 European health care systems, ranked Romania second from the bottom, just above Bulgaria, (www .healthpowerhouse.com/files/Report $\% 20$ EHCI\%202009\%20091005\%20final\%20 with\%20cover.pdf).

Romania performed poorly in all six subcategories. It ranked at the bottom of health care outcomes, infant mortality rate, heart fatality, cancer death and preventable years of life lost. It also ranked as the worst nation on such measurements as informal payments to doctors, inequity in access to services and drugs, including new cancer drugs.

Where to begin a fix?

"Romanian hospitals need to be run as professional service corporations, paying doctors and other staff decent salaries to work for their main employers and there only, at the same time doing away with the need for patients to pay doctors additional unofficial payments under the table. Hospitals and clinics should receive performancebased financing — no block grants," says Dr. Arne Björnberg, director of the Euro Consumer Health Index.

Still, some argue that the system has had its successes, particularly in comparison to the level of health care provided when the country was a Communist nation, prior to 1990 .

A decade ago, computed tomography scans were a luxury available in few hospitals, public or private. Today, they are still not ubiquitous, but at least most large hospitals offer them. The same is true for many technologies and therapies such as minimally invasive surgeries.

Whether the public health care system will be able to build on those successes and survive is unclear, however. For now, it seems like a patient with multiple morbidities. — Irina Haivas, Bucharest, Romania

DOI:10.1503/cmaj.109-3210 